\title{
Reflecting on our society?
}

Welcome to the winter 2018 issue of AJHPE. Both the quantitative and qualitative research paradigms are represented; therefore, there is something for everyone. What struck me was how reflective of society this issue is, as it contains articles on stress, gender-based violence and use of social media. It was also interesting to note that several topics seem to be in pairs - I am sure it was not intentional!

The topic of research in undergraduate curricula is addressed from two different perspectives, but both relate to students. In an undergraduate student study by Van Aswegen et al..$^{[1]}$ the association between personality factors and chosen area of specialty of medical practitioners was explored. The authors identified personality types in some specialties and differences between characteristics of local specialists; these were compared with findings from other studies. In contrast, the second study that involved students sought to determine optometry students' attitudes towards research. Coetzee and Kruger ${ }^{[2]}$ report that, while students recognised several benefits to undertaking research, the time-consuming nature of conducting research and the administrative processes associated with obtaining ethical approval were viewed negatively. These findings reflect the reality of conducting research. Langtree et al. ${ }^{[3]}$ report on factors contributing to stress in nursing students, whereas Moodley et al. ${ }^{[4]}$ address stress in the dental profession. While the causes of stress were different in these two study cohorts, both studies recommend the inclusion of stress management programmes in undergraduate curricula. The use of social media in learning is addressed in another pair of articles. Naidoo et al. ${ }^{[5]}$ found that most students in their occupational therapy sample used some form of social media and that participants were aware of the ethical dilemmas inherent in using these media. Osaigbovo and Iwegim ${ }^{[6]}$ report on the use of Instagram and Facebook to complement lectures in the teaching of medical microbiology in Nigeria. Their post-intervention survey showed that engagement with material and postings were higher in Instagram.

Using the Delphi technique, Fawole et al. ${ }^{[7]}$ sought to obtain consensus from teachers on a gender-based violence curriculum for medical schools in Nigeria. The study identified topics for inclusion, level of study at which the curriculum should be taught, methods of teaching and who should teach. Interestingly, the written examination ranked highest as the method of assessment. Using the mnemonic AIMED AT ITCHEDD, Makkink and Vincent-Lambert ${ }^{[8]}$ conducted a survey to determine teachers' and students' opinions on the use of the mnemonic in teaching and learning critical thinking and decision-making in patient management. The mnemonic was generally well perceived by teachers and students alike. The article by Burch et al. ${ }^{[9]}$ reminded me of Paulo Freires ${ }^{[10]}$ work, Pedagogy of the Oppressed. Freire believed that learners do not enter tertiary institutions as blank slates. Burch et al. ${ }^{[9]}$ studied the self-reported proficiency levels of medical students in six categories of generic learning skills and found a significant relationship with pre-university admission aptitude test scores, information technology proficiency on entry to university and early academic performance at university. Furthermore, academically weak students did not overestimate their skills proficiency.

Pillay et al. ${ }^{[11]}$ compared teaching methods used in an anatomy course with the critical cross-field outcomes specified by the South African Qualifications Authority. This form of reviewing the curriculum led to changes in teaching methods that enabled better alignment of achievement of the cross-field outcomes.

I hope this brief summary of some of the contents of this issue of AJHPE piques your interest and motivates you to read this edition from cover to cover.

\section{Patricia McInerney}

Centre for Health Science Education, Faculty of Health Sciences, University of the Witwatersrand, Johannesburg, South Africa patricia.mcinerney@wits.ac.za

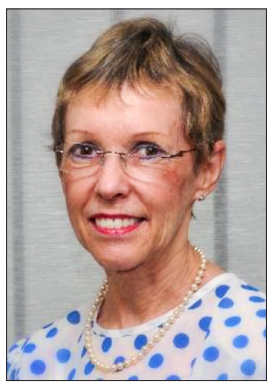

Van Aswegen R, Ravgee A, Connellan G, et al. Association between personality factors and consulting specialty of practice of doctors at an academic hospital in Bloemfontein, South Africa. Afr J Health Professions Edu 2018;10(2):79-84. https:// doi.org/10.7196/AJHPE.2018.v10i2.997

2. Coetzee L, Kruger SB. Optometry students' attitudes towards research at undergraduate level. Afr J Health Professions Educ 2018;10(2):85-89. https://doi.org/10.7196/AJHPE.2018.v10i2.728

3. Langtree EM, Razak A, Haffejee F. Factors causing stress among first-year students attending a nursing college in KwaZulu-Natal, South Africa. Afr J Health Professions Educ 2018;10(2):90-95. https://doi.org/10.7196 AJHPE.2018.v10i2.993

4. Moodley R, Naidoo S, van Wyk J. 'Pain and stress are part of my profession': Using dental practitioners' views of occupation-related factors to inform dental training. Afr J Health Professions Educ 2018;10(2):96-100. https: doi.org/10.7196/AJHPE.2018.v10i2.1005

5. Naidoo D, Govender P, Stead M, Mohangi U, Zulu F, Mbele M. Occupational therapy students' use of social media for professional practice. Afr J Health Professions Educ 2018;10(2):101-105. https://doi.org/10.7196/ AJHPE.2018.v10i2.980

6. Osaigbovo II, Iwegim CF. Instagram: A niche for microlearning of undergraduate medical microbiology. Afr J Health Professions Educ 2018:10(2):75. https://doi.org/10.7196/AJHPE.2018.v10i2.1057

7. Fawole OI, van Wyk J, Adejimi AA, Akinsola OJ, Balogun O. Establishing consensus among inter-professiona Fawole OI, van Wyk J, Adejimi AA, Akinsola OJ, Balogun O. Establishing consensus among inter-professional
faculty on a gender-based violence curriculum in medical schools in Nigeria: A Delphi study. Afr J Health faculty on a gender-based violence curriculum in medical schools in Nigeria: A D
Professions Educ 2018;10(2):106-113. https://doi.org/10.7196/AJHPE.2018.v10i2.988

8. Makkink A, Vincent-Lambert C. AIMED AT ITCHEDD: A proof-of-concept study to evaluate a mnemonicbased approach to clinical reasoning in the emergency medical care educational setting. Afr J Health Profession Educ 2018;10(2):76-78. https://doi.org/10.7196/AJHPE.2018.v10i2.543

9. Burch VC, Sikakana CNT, Gunston GD, Murdoch-Eaton D. Self-reported generic learning skills proficiency: Another measure of medical school preparedness. Afr J Health Professions Educ 2018;10(2):114-123. https://doi. org/10.7196/AJHPE.2018.v10i2.97

10. Freire P. Pedagogy of the Oppressed. London: Penguin Books, 1972.

11. Pillay JD, Govender N, Lachman N. Integrating critical cross-field outcomes in an anatomy course at a university of technology: A reflective perspective. Afr I Health Professions Educ 2018:10(2):XXX. https://doiorg/10.7196 AJHPE.2018.v10i2.960

Afr J Health Professions Educ 2018;10(2):74. DOI:10.7196/AJHPE.2018.v10i2.1108 